\title{
PRISONER VOTING AND DEVOLUTION: NEW DIMENSIONS TO AN OLD DISPUTE
}

\author{
C.R.G. Murray *
}

\section{Keywords}

Right to Free and Fair Elections - Prisoners - Devolution - Scotland - Wales

\begin{abstract}
Between late 2017 and 2018 the United Kingdom and the Council of Europe called a truce over prisoner voting rights, and almost no one noticed. No bells rang out, no triumphal debate took place in Westminster. All protagonists had long since exhausted their energies or, at least, turned their attentions to the United Kingdom's withdrawal from the European Union. This article evaluates the "Lidington Compromise", by which the UK Government moved to enfranchise day-release prisoners, alongside Scottish and Welsh Parliaments opening up new aspects of the confrontation by moving to enfranchise some prisoners on the basis of sentence length. It assesses the significance of these moves in the context of devolution. It also examines how these different approaches to resolving the prisoner voting issue square with the Strasbourg Court's jurisprudence and the extent to which different understandings of democratic rights now prevail across the United Kingdom.
\end{abstract}

\footnotetext{
* Reader, Newcastle Law School (UK). My thanks to Greg Davies (Cardiff University), Aoife O'Donoghue (Durham University), Christopher McCorkindale (University of Strathclyde), Hélène Tyrrell (Newcastle University) and Ian Ward (Newcastle University) for their advice and comments upon earlier drafts of this article. All hyperlinks have been updated as of 1 February 2021. Any errors remain my own.
} 


\section{Contents}

\section{A. INTRODUCTION}

B. PRISONERS AND THE RIGHT TO VOTE

(1) Prisoner Voting before the European Court of Human Rights

(2) Implementing the UK's Obligations under the European Convention

C. DE-ESCALATING THE UK-STRASBOURG CONFRONTATION

D. DEVOLUTION AND PRISONER VOTING

(1) Scotland

(2) Wales

E. "BALANCING" THE RIGHT TO VOTE AND PENAL POLICY CONSIDERATIONS

F. CASES YET TO COME

G. REFERENDUMS YET TO COME

H. CONCLUSION 


\section{A. INTRODUCTION}

The Grand Chamber of the European Court of Human Rights has characterised the right to free and fair elections under the European Convention on Human Rights (ECHR) as "crucial to establishing and maintaining the foundations of an effective and meaningful democracy governed by the rule of law". ${ }^{1}$ The right of individuals to participate in free and fair elections, however, far from being an uncontroversial and fundamental aspect of what it is for a society to conceptualise itself as a rights-respecting democracy, has been central to the UK's longrunning dispute with the European Court over prisoner voting. ${ }^{2}$ Narratives about the hollowing out of democratic values across a range of polities have proliferated in recent years, but these discussions sometimes end up harkening back to golden eras of democracy which left much to be desired. ${ }^{3}$ The issue of prisoner voting exposes the long-standing gaps in the application of universal adult citizen suffrage within the UK's governance order. Politicians might have long flaunted the "strength and vitality of our ancient democracy", as David Cameron did after the outcome of the Scottish independence referendum in $2014,{ }^{4}$ but prisoner voting highlights the limitations to core democratic principles within this order. The picture within the UK is, nonetheless, more complex than general accounts of the malaise of democracy might suggest, and this article examines recent extensions and proposed extensions of the voting rights of prisoners in the UK, and whether such engagement with this thorniest of issues affecting the core concept of universal suffrage has reinvigorated debates around democracy.

In late 2017, the UK Government took the unilateral step to enfranchise day-release prisoners. Two of the devolved administrations have, or are proposing to, pursue further reforms. The Scottish Parliament's passing of the Scottish Elections (Franchise and

\footnotetext{
${ }^{1}$ Hirst $v$ United Kingdom (No 2) (2006) 42 EHRR 41, [71].

${ }^{2}$ See E Bates, "Analysing the Prisoner Voting Saga and the British Challenge to Strasbourg" (2014) 14 Human Rights Law Review 503; S Fredman, "From dialogue to deliberation: human rights adjudication and prisoners' rights to vote" [2013] Public Law 292; C Murray, "Playing for Time: Prisoner Disenfranchisement under the ECHR after Hirst v United Kingdom" (2011) 22 King's Law Journal 309 and S Foster, "Reluctantly restoring rights: Responding to the prisoners' right to vote" (2009) 9 Human Rights Law Review 489.

${ }^{3}$ See N Bermeo, "On Democratic Backsliding" (2016) 27 Journal of Democracy 5; G O'Donnell, "The Perpetual Crises of Democracy" (2007) 18 Journal of Democracy 5 and M Kumm, J Havercroft, J Dunoff and A Wiener, "Editorial: The end of "the West" and the future of global constitutionalism" (2017) 6 Global Constitutionalism 1.

${ }^{4}$ D Cameron, "In full: David Cameron statement on the UK's future" BBC News (19 September 2014). Available at: https://www.bbc.co.uk/news/uk-politics-29271765.
} 
Representation) Act 2020 enfranchises all prisoners serving terms of under one year. In Wales, a Parliamentary Committee has proposed the enfranchisement of all prisoners serving terms of under four years, and the devolved Government has pledged to take forward reforms after the 2021 Senedd Cymru/Welsh Parliament elections. The question remains, however, whether these moves demonstrate democratic institutions engaging in a meaningful evaluation of the nature of the democratic order. Conor Gearty has questioned the security of democratic values in the UK's governance order, and even conjectured that "the vagaries of international relations (including war and the fear of war) that have done more to embed democracy than any amount of good arguments or collectivist expressions of solidarity". 5 This paper highlights how, under the baleful influence of the supermajority requirements imposed in the Scotland Act 2016 and Wales Act 2017, these debates over prisoner voting have drawn less upon the presumption in favour of enfranchisement in a democratic order and more upon boilerplate assertions of the need to act to rectify a breach of the ECHR.

\section{B. PRISONERS AND THE RIGHT TO VOTE}

(1) Prisoner Voting before the European Court of Human Rights

The general disenfranchisement of prisoners under section 3 of the Representation of the People Act 1983 has been the most enduring and for long periods most high-profile breach of the UK's international human rights commitments in recent decades. The duration of the UK's breach and the challenges by successive UK Governments to both the decision and remit of the European Court of Human Rights on this issue have nonetheless increased its significance. ${ }^{6}$ The Court's basis for finding UK electoral law incompatible with the right to free and fair elections in Hirst was two-fold. First, the penalty of disenfranchisement operates in an arbitrary manner (especially in short-sentence cases), with its imposition depending on little more than whether someone is imprisoned on the date of an election. ${ }^{7}$ Second, the statutory restrictions on prisoners' voting, in effect since the enactment of the Representation of the People Act 1969, was not subject to any meaningful explanation in Parliament. ${ }^{8}$

\footnotetext{
${ }^{5}$ C Gearty, 'Neo-Democracy: 'Useful Idiot' of Neo-Liberalism?” (2016) 56 British Journal of Criminology 1087, 1090.

${ }^{6}$ See A von Staden, Strategies of Compliance with the European Court of Human Rights: Rational Choice Within Normative Constraints (UPP, 2018) pp 135-141.

${ }^{7}$ Hirst $v$ United Kingdom, n 1, [82].

${ }^{8}$ Ibid, [79].
} 
Substantive responses to the Hirst decision have focused upon imprisonment as an appropriate threshold for disenfranchisement. The UK Government has maintained its justification for prisoner disenfranchisement as "enhancing civic responsibility and respect for the rule of law by depriving those who had breached the basic rules of society of the right to have a say in the way such rules were made for the duration of their sentence". 9 The European Court has never dismissed these concerns, asserting that there is "no reason ... to exclude these aims as untenable or per se incompatible with the right", and thereby conceding that some restrictions on the ability of some prisoners to vote are justifiable. ${ }^{10}$ The dispute between the UK and the Court is thus focused upon the compatibility of the UK's threshold for disenfranchisement being post-sentencing imprisonment for all offences other than contempt of court or defaulting on a fine. For Strasbourg, in a democratic society the "presumption" in favour of an adult citizen franchise could not be so lightly displaced. ${ }^{11}$

Since Hirst, Strasbourg has maintained that such a general restriction upon prisoners voting fails to give adequate regard to the fundamental importance of the vote in a democracy. ${ }^{12}$ In Scoppola, however, the Grand Chamber reaffirmed that efforts to enhance civic responsibility constituted "legitimate aims", ${ }^{13}$ and even accepted that in some circumstances disenfranchisement can legitimately continue after imprisonment. ${ }^{14}$ In subsequent cases the Court has denied the application of the right to vote to referendums ${ }^{15}$ and denied damages or legal costs for ongoing breaches of the right, ${ }^{16}$ removing much of the incentive to bring claims for some prisoners. The European Court has therefore hardly been insensitive to the margin of appreciation which States enjoy under Article 3 of Protocol 1 in the arrangement of their electoral systems. ${ }^{17}$ These efforts to de-escalate the clash over prisoner voting, however, have been interpreted as Strasbourg being irresolute over Hirst. The Court might not have repudiated the judgment, but as Adam Tomkins characterised its

\footnotetext{
${ }^{9}$ Ibid, [50].

${ }^{10}$ Ibid, [75].

${ }^{11}$ Ibid, [59].

${ }^{12}$ Scoppola v Italy (No 3) (2013) 56 EHRR 19, [104].

${ }^{13}$ Ibid, [92].

${ }^{14}$ Ibid, [109].

${ }^{15}$ McLean and Cole v United Kingdom (2013) 57 EHRR SE8, [32]-[33].

${ }^{16}$ Firth v United Kingdom App 47784/09 (12 August 2014), [18]; McHugh v United Kingdom App 51987/08 (10 February 2015), [17].

${ }^{17}$ See R Ziegler, "Voting Eligibility: Strasbourg's Timidity" in K Ziegler, E Wicks and L Hodson (eds), The UK and European Human Rights: A Strained Relationship (Hart, 2015) 165.
} 
jurisprudence in withering vernacular before the Scottish Parliament, it could be said to have "swithered on it". 18

(2) Implementing the UK's Obligations under the European Convention

If this case law demonstrates that the scope of obligations associated with free and fair elections was still being determined by Strasbourg, recent years have also seen shifts in how the responsibility for maintaining this right operates within the UK. The extension of devolved competences to make provision for changes to the franchise in Wales and Scotland, but not Northern Ireland, will be examined in detail below, but it is first necessary to contextualise how the UK's international human rights obligations apply to the work of Westminster and the devolved legislatures. Where an international human rights obligation is at issue, the UK as a state assumes the obligation and would not, for example, be able to plead inaction by devolved institutions in response to claims that it was in breach of these international obligation. ${ }^{19}$ The Strasbourg Court has, however, acknowledged a "federal" aspect to its margin of appreciation jurisprudence, accepting that constituent parts of a state are able to make different choices in terms of the relationship between individual and community interests where qualified rights are at issue. ${ }^{20}$

The overarching international obligation on the UK as a state has seen the UK Government step in to rectify breaches of human rights within devolved competences, most notably with regard to reproductive rights in Northern Ireland. Once the UK Supreme Court had recognised that the law in effect in Northern Ireland breached the Article 8 of the ECHR, ${ }^{21}$ pressure fell upon Westminster to rectify the breach, because at the time of the ruling Northern Ireland's devolved legislature and executive had collapsed and devolved

\footnotetext{
${ }^{18}$ A Tomkins MSP, Scottish Parliament Official Report, 28 November 2019, col 99.

${ }^{19}$ Under the ECHR, the obligation to secure the Convention rights under international law falls on each High Contracting Party in regard to its jurisdiction; Convention for the Protection of Human Rights and Fundamental Freedoms (1953) 213 UNTS 222, Article 1. See D Harris, M O'Boyle, E Bates and C Buckley, Harris, O'Boyle, and Warbrick: Law of the European Convention on Human Rights ( $4^{\text {th }}$ Ed, Oxford University Press, 2018) pp 29-31

${ }^{20}$ See, for example, Mouvement Raëlien Suisse v Switzerland (2013) 56 EHRR 14, [64].

${ }^{21}$ In re Northern Ireland Human Rights Commission [2018] UKSC 27; [2018] NI 228, [2]. The Supreme Court indicated that the law in effect in Northern Ireland breached Article 8 but ruled, by a 4:3 majority, that the Northern Ireland Human Rights Commission did not possess standing to bring the action.
} 
governance continued without a policy-making function. ${ }^{22}$ The enactment of the Northern Ireland (Executive Formation etc) Act 2019 recognised the duty upon the Northern Ireland Secretary to act expeditiously to rectify this breach if the full workings of the power-sharing institutions were not promptly restored, in light of "the importance of doing so for protecting the human rights of women in Northern Ireland". ${ }^{23}$ In giving effect to this duty, the UK Government subsequently confirmed that it was obliged to legislate because the issue was receiving "ongoing attention at Westminster on human rights grounds". ${ }^{24}$

In terms of domestic law, the picture is more nuanced. The provisions of the Human Rights Act 1998, incorporating elements of the ECHR into the UK's legal systems, have been said to provide a common baseline for rights protection across the different parts of the UK. ${ }^{25}$ Those standards operate very differently depending on whether devolved or Westminster legislation is at issue. With regard to statutes passed at Westminster, the creation of the power of the courts to reinterpret legislation in a rights-compliant manner and to issue declarations of incompatibility where this was not possible were explicitly designed to prevent the courts from possessing the power to strike down primary legislation. ${ }^{26}$ For devolved law-making, a much more hard-edged obligation operates by which measures which breach the incorporated ECHR rights are beyond the competence of any of the devolved legislatures. ${ }^{27}$ The devolution statutes thereby provide the devolved institutions 'no power to do any act which is incompatible with Convention rights' ${ }^{28}$ and require the courts 'strike down all and any "unconstitutional" acts of the devolved legislature'. ${ }^{29}$

One of the most difficult issues in terms of human rights compliance that emerges from this web of obligations is with regard to "legacy" enactments by the UK Parliament,

\footnotetext{
${ }^{22}$ Prior to this ruling the UK Government had long resisted any suggestion that Westminster legislate on reproductive rights in Northern Ireland; see J Thomson, "Explaining gender equality difference in a devolved system: The case of abortion law in Northern Ireland" (2016) 11 British Politics 371.

${ }^{23}$ Northern Ireland (Executive Formation etc) Act 2019, s 9(7).

${ }^{24}$ R Walker MP, HC Deb, vol 676, col 1019 (4 June 2020).

${ }^{25} \mathrm{~N}$ Walker, "The Territorial Constitution and the Future of Scotland" in A McHarg, T Mullen, A Page and N Walker (eds), The Scottish Independence Referendum: Constitutional and Political Implications (Oxford University Press, 2016) 247, p 269.

${ }^{26}$ A Young, Parliamentary Sovereignty and the Human Rights Act (Hart, 2009) 1.

${ }^{27}$ Scotland Act 1998, s 29(2)(d); Government of Wales Act 2006, s 108A(2)(e); Northern Ireland Act 1998, s 6(2)(c).

${ }^{28}$ In re Northern Ireland Human Rights Commission, $\mathrm{n}$ 21, [337] (Lord Reed).

${ }^{29}$ A O’Neill, "Stands Scotland Where it Did? Devolution, Human Rights and the Scottish Constitution Seven Years On” (2006) 57 Northern Ireland Legal Quarterly 102, 106.
} 
which cover areas of competence that have subsequently been devolved. Pieces of legislation passed by each of the devolved legislatures "within its legislative competence enjoy ... the highest legal authority". ${ }^{30}$ Devolved legislatures are therefore able to legislate to rectify human rights breaches resultant from Westminster legislation which is within their areas of competence, but questions remain over the extent to which they are compelled to do so. In his judgment regarding the Northern Ireland Human Rights Commission's challenge to the continued operation of sections 58 and 59 of the Offences Against the Person Act 1861 as the law applicable to abortion in Northern Ireland, Lord Mance emphasised that '[n]either the Westminster Parliament's enactment of, nor its or the Northern Irish legislature's failure to repeal or amend, the 1861 Act can constitute an "unlawful act" under sections 6 and 7 of the [Human Rights Act]'. ${ }^{31}$ Although he led the majority in finding that the Human Rights Commission did not enjoy standing, he did accept that the law breached Article 8, and concluded that ' $[t]$ hose responsible for ensuring the compatibility of Northern Ireland law with the Convention rights will no doubt recognise and take account of these conclusions, at as early a time as possible'. ${ }^{32}$ Where the responsibility to address this breach ultimate lies is deliberately obscured by Lord Mance's language. Baroness Hale, had she commanded a majority, would have used a declaration of incompatibility to 'place the ball in Parliament's court', but that statement was perhaps predicated on the moribund state of the Northern Ireland Assembly at the time. ${ }^{33}$ Reading between the lines of these statements, it is incumbent upon devolved institutions to respond to the court's identification of human rights breaches within their areas of competence. In these circumstances earlier case law accepts that a devolved legislature could "decline to legislate", but if it chooses to do so "it will be outside its competence to legislate in a way that is incompatible with any of the Convention rights". ${ }^{34}$ Should it "decline to legislate", however, Westminster will have the opportunity to make good the shortfall. Much as none of the devolved administrations would relish the prospect of Westminster acting in such a way, the possibility is at present no more than notional in the context of prisoner voting.

\footnotetext{
${ }^{30}$ AXA General Insurance Ltd v Lord Advocate (Scotland) [2011] UKSC 46; [2012] 1 AC 868, [56] (Lord Hope).

${ }^{31}$ In re Northern Ireland Human Rights Commission [2018] UKSC 27; [2018] NI 228, [58] (Lord Mance).

${ }^{32}$ Ibid, [135].

${ }^{33}$ Ibid, [40].

${ }^{34}$ In re G (Adoption: Unmarried Couple) [2008] UKHL 38; [2009] AC 173, [46] (Lord Hope).
} 


\section{DE-ESCALATING THE UK-STRASBOURG CONFRONTATION}

Just as the European Court was looking for a way out of the crisis in decisions such as Scoppola, McLean and Cole, Firth and McHugh, under Chris Grayling's tenure as Secretary of State for Justice/Lord Chancellor, the UK Government was raising the stakes around the issue by proposing new legislation, the Draft Voting Eligibility (Prisoners) Bill 2012, which included an option to sustain the general exclusion of prisoners from the franchise and assert the rationale behind this exclusion during the legislative process. ${ }^{35}$

In cases such as Chester ${ }^{36}$ and Moohan ${ }^{37}$ the UK Supreme Court made little effort to push the UK Government towards addressing the ongoing breaches of the right to vote, not least because, with the European Court apparently wavering, the justices had no desire to reenergise the confrontation. Many of their interventions, indeed, gave succour to the UK Government's cause. Lord Mance saw the issue as primarily one for Parliament to resolve. ${ }^{38}$ For Baroness Hale, prisoners "have all committed an offence deemed serious enough to justify their removal from society", ${ }^{39}$ and by extension this could be taken as justifying the exclusion of all prisoners from democratic decisions over how society is governed. Lord Sumption, with the agreement of Lord Hughes, presented a history of restrictions upon prisoner voting "mainly the incidental consequence of other rules of law", ${ }^{40}$ but that the "the automatic character of the exclusion of convicted prisoners from the franchise", in place since 1969 , had effectively been rationalised on the basis that "the principle that sentences of imprisonment are imposed only for the more serious offences". ${ }^{41}$ Lord Hodge thereafter capped these interventions by pouring cold water on any applicable common law protections for democracy. ${ }^{42}$

\footnotetext{
${ }^{35}$ UK Government, Voting Eligibility (Prisoners) Draft Bill (2012) Cm 8499, para 39-40. The Lord Chancellor made no secret of the UK Government's support for maintaining the status quo; C Grayling MP, HC Deb, vol 553, col 745 (22 November 2012).

${ }^{36} R$ (Chester) v Secretary of State for Justice [2013] UKSC 63, [2014] 1 AC 271.

${ }^{37}$ Moohan v Lord Advocate [2014] UKSC 67, [2015] 1 AC 901.

${ }^{38} R$ (Chester) $v$ Secretary of State for Justice [2013] UKSC 63, [19].

${ }^{39}$ Ibid, [91].

${ }^{40}$ Ibid, [126].

${ }^{41}$ Ibid, [129]. Lord Clarke, at [105], was careful to outline the reasons why he was "less critical than Lord Sumption of the decisions of the European Court of Human Rights".

${ }^{42}$ Moohan v Lord Advocate [2014] UKSC 67, [35] (Lord Hodge).
} 
Parliament, however, undercut Grayling's push for all-out victory in the dispute. A Joint Committee of the House of Commons and Lords was appointed to provide for prelegislative scrutiny of the Draft Bill proposals, with its deliberations ranging across the nature of democracy. It concluded that "[i]n a democracy all citizens possess a presumptive right to vote, thereby having a say in the making of the laws that govern them" and that "[t]he existence of such a right is the necessary corollary of universal suffrage". ${ }^{43}$ In 2013 the Committee Report, supported by a majority of its members, proposed that the enfranchisement of prisoners serving less than one year, together with prisoners serving longer sentences in the final six months of their incarceration, would provide the best route by which to satisfy the UK's legal obligations under the ECHR. ${ }^{44}$ These proposals received little response from ministers, but in the wake of the Committee Report the Draft Bill was quietly shelved. ${ }^{45}$ In subsequent years prisoner voting came to be regarded as an intractable dispute, the attention it once received in constitutional discourse being usurped by the Scottish independence referendum and Brexit. ${ }^{46}$

The issue's reduced prominence did give the UK Government the opportunity to explore a way out of the impasse. In late 2017 reforms, instituted during David Lidington's tenure as Secretary of State for Justice/Lord Chancellor, provided for at least a temporary fix. The Lidington Compromise was two-fold in its effect, making explicit the removal of voting rights upon sentencing and also enfranchising prisoners on temporary day release on the date of an election. ${ }^{47}$ This was an administrative solution, explicitly intended to offer a minor concession towards the human rights concerns at issue without having to justify legislation before the UK Parliament. On any given day it affects a mere 100 prisoners out of a UK prison population of over 80,000 . These measures were communicated to the Council of Europe's Committee of Ministers, which subsequently closed the Hirst group of cases as having been effectively resolved. ${ }^{48}$

\footnotetext{
${ }^{43}$ Joint Committee on the Draft Voting Eligibility (Prisoners) Bill, Draft Voting Eligibility (Prisoners) Bill (18 December 2013) HL 103/HC 924, para 154.

${ }^{44}$ Ibid, p 67.

${ }^{45}$ See H Hardman, "In the name of Parliamentary Sovereignty: Conflict between the UK Government and the courts over judicial deference in the case of prisoner voting rights" (2020) 15 British Politics 226, 242.

${ }^{46}$ Prisoner voting did arguably have a walk on role in Brexit debates, as Vote Leave argued that the EU which was pushing the UK into enfranchising prisoners; see C Murray, "Monstering Strasbourg over Prisoner Voting Rights" in M Farrell, E Drywood, and E Hughes (eds), Human Rights in the Media: Fear and Fetish (Routledge, 2019) 101, p 111.

${ }^{47}$ D Lidington, MP, HC Deb, vol 630, col 1007 (2 November 2017).

${ }^{48}$ Council of Europe, Committee of Ministers, 1324th meeting, 7 September 2018 (DH), para
} 
Although a relieved Committee of Ministers accepted the Lidington Compromise as closing the Hirst case, the reforms did little to address the problems the Court had identified. In its prisoner voting jurisprudence, the European Court has required that a specific rationale must be identified for imposing voting restrictions upon some prisoners, as opposed to an "automatic and indiscriminate" rule with a general effect on prisoners. ${ }^{49}$ The Court's acceptance of this arrangement as ECHR compliant would thus amount to a major climbdown from its jurisprudence on the necessary requirements of the right to free and fair elections, although its denial of costs and damages decreases the likelihood that this will be tested by further claims in the immediate future. The UK Government's minimal response does not, therefore, satisfy the principles underpinning the European Court's jurisprudence, even taking into account the "the wide margin of appreciation in this area" ${ }^{50}$ The margin of appreciation, moreover, acknowledges that domestic institutions are often better placed than the Court when it comes to assessing the application of the ECHR within a particular legal system; it does not, by extension, insulate these arrangements from challenge before the domestic courts. The Hirst case might have been resolved, but the possibility of further successor litigation has not been averted. With this concern in mind, prisoner voting has come onto the agenda of the Scottish and Welsh Parliaments.

\section{DEVOLUTION AND PRISONER VOTING}

In the course of the Scottish independence referendum campaign the UK Government made pledges about a new devolution settlement with enhanced powers for the Scottish Parliament if the people of Scotland voted to remain part of the UK. ${ }^{51}$ These enhanced powers would introduce new competences with regard to elections in Scotland. ${ }^{52}$ In the aftermath of the referendum vote, the UK Parliament made good on this pledge through the enactment of the Scotland Act 2016. ${ }^{53}$ Wales was not to be left behind in this new dispensation, and through

18.

${ }^{49}$ Scoppola v Italy, $\mathrm{n}$ 12, [108]. The European Court has also explicitly sought a legislative solution to the breach; Greens and MT v United Kingdom (2011) 53 EHRR 21, [110]-[115].

${ }^{50}$ Council of Europe Committee of Ministers, 1302nd meeting, 5-7 December 2017 (DH), H4639 , para 3.

${ }^{51}$ These promises were restated in HM Government, Scotland in the United Kingdom: An enduring settlement (2015) Cm 8890.

${ }^{52}$ Ibid, $\mathrm{p}$ 17. See also The Smith Commission, Report of the Smith Commission for further devolution of powers to the Scottish Parliament (27 November 2014), para 23.

${ }^{53}$ Scotland Act 2016, ss 3-11. 
the Wales Act 2017 the Welsh Parliament also gained the competence to alter its own electoral arrangements and those applicable to local government in Wales. ${ }^{54}$ Highlighting the ongoing asymmetry of devolution arrangements, there was no comparable transfer of competences to the Northern Ireland Assembly. This is perhaps unsurprising in light of the history of manipulation of electoral processes in the era of devolution to Northern Ireland between 1921 and $1972 .{ }^{55}$ It is also reflective of the unstable nature of power sharing in Northern Ireland. Between the enactment of the Scotland Act and Wales Act, the Northern Ireland Assembly collapsed amid acrimony over the management of the Renewable Heat Incentive scheme. Its doors would remain closed for three years, and even after power sharing recommenced in January $2020,{ }^{56}$ its ongoing fragility militates against extensions of its competences. ${ }^{57}$ Even if some adjustment to franchise rules for Northern Ireland's local government elections might well be necessary to reflect the requirements of the Brexit deal, any such reforms will thus have to be instituted through Westminster legislation. ${ }^{58}$

The new competences of the Scottish and Welsh Parliaments with regard to electoral law, however, came with a catch. Powers altering the electorate, the voting system, the number of constituencies and the number of representatives to be elected are only able to be exercised if supported by a super majority of legislators. The drafting of these provisions requires that at least two thirds of all legislators, not legislators voting on the measure, back the reform in question. In the context of Scotland, this means that 86 of the 129 MSPs must

\footnotetext{
${ }^{54}$ Wales Act 2017, ss 5-10. For an overview of these measures with regard to Wales and Scotland, see Law Commission and Scottish Law Commission, Electoral Law: A Joint Final Report (2020) Law Com No 389/Scot Law Com No 256, para 2.32-2.36.

${ }^{55}$ With regard to the replacement of proportional representation for Stormont elections with a first-past-the-post system, under the House of Commons (Method of Voting and Redistribution of Seats) Act (Northern Ireland) 1929, see R Osborne, "The Northern Ireland parliamentary electoral system: The 1929 reapportionment" (1979) 12 Irish Geography 42 and D Pringle, "Electoral Systems and Political Manipulation: A Case Study of Northern Ireland in the 1920s" (1980) 11 Economic and Social Review 187.

${ }^{56}$ New Decade, New Approach (8 January 2020). Available at:

https://assets.publishing.service.gov.uk/government/uploads/system/uploads/attachment_data/fil e/856998/2020-01-08_a_new_decade_a_new_approach.pdf.

${ }^{57}$ See S Haughey, "Back to Stormont: The New Decade, New Approach Agreement and What it Means for Northern Ireland" (2020) 91 Political Quarterly 134.

${ }^{58}$ The Ireland/Northern Ireland Protocol protects rights which can be connected to the Belfast Agreement and which are dependent upon European Union law; this provides an arguable basis for maintaining the rights of EU citizens to vote in local government elections in Northern Ireland; Agreement on the Withdrawal of the United Kingdom of Great Britain and Northern Ireland from the European Union (30 January 2020), Protocol on Ireland/Northern Ireland, Article 2(1).
} 
support a change in the law, ${ }^{59}$ and in Wales a measure requires the support of 40 of the 60 Assembly Members to become law. ${ }^{60}$ These requirements were not imposed to restrict the possibility of measures being introduced which undermine the right to vote. Such protections would have been framed in a way which prevented the Scottish and Welsh Parliaments from removing the vote from any group without achieving a super majority. Rather, the UK Government's aim, as summarised by the Constitution Committee, was "to ensure that electoral laws are not changed for the advantage of a particular party". ${ }^{61}$ The framing of these measures nonetheless creates the suspicion that the underlying purpose was to prevent Scotland and Wales from legislating to enfranchise prisoners in elections for their Parliaments and local elections within their jurisdictions and thereby embarrassing the Westminster Government.

These new competences thus created something of a trap. Should any new measure be introduced to affect voting rights by the Scottish or Welsh Parliaments they would be obliged to consider reform of prisoner voting restrictions to meet their human rights obligations. As the Constitution Committee has pointed out, the UK Government was unable to issue a certificate of compatibility as set out in section 19 of the Human Rights Act 1998 for the House of Lords Reform Bill in 2012, because its conception of elections for members of Westminster's upper chamber made no provision for reform of prisoner voting. ${ }^{62}$ The Scottish Government was aware that it would have to tackle the issue of prisoner voting as a facet of exercising these new powers as the issue had been previously raised in debates over the special franchise rules enacted for the 2014 Scottish independence referendum. ${ }^{63}$ The Scottish Government's refusal to countenance any reform of the restrictions contained in the Representation of the People Act 1983 in preparations for the independence referendum was actively litigated by prisoners leading, as we have seen, to the courts side-stepping the issue by confirming that the right under Article 3 of Protocol 1 is restricted to elections. ${ }^{64}$ Unlike the UK Parliament, as discussed above, the Scottish and Welsh Parliaments are subject to the binding effect of the UK's incorporated ECHR commitments; it is beyond their legislative

\footnotetext{
${ }^{59}$ Scotland Act 2016, s 11.

${ }^{60}$ Wales Act 2017, s 9.

${ }^{61}$ Constitution Committee, Proposals for the Devolution of Further Powers to Scotland (2015)

HL 145, para 92.

${ }^{62}$ Constitution Committee, Proposals for the Devolution of Further Powers to Scotland (2015) HL 145, para 88 and Constitution Committee, Wales Bill (2016) HL 59, para 78.

${ }^{63}$ See Scottish Parliament Official Report, 27 June 2013, col 21795.

${ }^{64}$ See Moohan, n 37.
} 
competence to breach its requirements. These provisions therefore combined to create an obligation on the devolved institutions to address prisoner disenfranchisement as part of any reform of the franchise they sought to undertake, ${ }^{65}$ even though there may not be sufficient support within the Scotland and Wales' legislatures to meet the super majority required by the enabling statutes. This conundrum unsurprisingly meant that prisoner voting has come to be regarded in both systems as something of a trap.

\section{(1) Scotland}

The Scottish Parliament had the first opportunity to consider prisoner voting, as the commencement of the powers over electoral law came into effect in May 2017, almost a year ahead of the equivalent powers for the Welsh Parliament. ${ }^{66}$ This is perhaps appropriate; the legal restrictions on prisoner voting under the Scots law had historically been distinct from the rules operating in the remainder of the UK, and as a result claims that general disenfranchisement really was "a fundamental and long-standing part of the prison process" were particularly dubious in the context of Scotland. ${ }^{67}$

Legislative reforms in 1949 saw the formal abolition of the concept of outlawry in Scots law, and with it a general impediment to prisoner voting ${ }^{68}$ coincide with the nearsimultaneous introduction of postal voting for elections across the UK for voters "no longer resident at their qualifying address". ${ }^{69}$ Between this change and the enactment of the Representation of the People Act 1969, all prisoners in Scotland, no matter the seriousness of their offence, were able to vote by post for as long as their names remained on the electoral register. ${ }^{70}$ In effect, these measures allowed prisoners to vote for up to one year into their sentences before the administrative process of updating the electoral register removed their name from their place of residence prior to imprisonment. Indeed, litigation by prisoners held in Scotland seeking to vote in the mid-1960s demonstrates that tension between prisoner

\footnotetext{
${ }^{65}$ See In Re G, n 34.

${ }^{66}$ The Scotland Act 2016 (Commencement No 6) Regulations 2017 (SI 2017/608); The Wales Act 2017 (Commencement No 4) Regulations 2017 (SI 2017/1179).

${ }^{67}$ See N Sturgeon MSP, Scottish Parliament Official Report, 27 June 2013, col 21802.

${ }^{68}$ Criminal Justice (Scotland) Act 1949, s 15(2).

${ }^{69}$ Representation of the People Act 1948 (UK), s 8(1)(e).

${ }^{70}$ See C Murray, "A Perfect Storm: Parliament and Prisoner Disenfranchisement” (2013) 66

Parliamentary Affairs 511, 519-520.
} 
disenfranchisement and the right to vote long pre-dates Hirst. ${ }^{71}$ The prisoners in question were not prevented from voting because they had been imprisoned, but on the technicality that because Saughton Prison (HMP Edinburgh) was in their "home" constituency, no postal vote could be issued. The case illustrates how other prisoners, not affected by this quirk of the postal voting system, were able to vote. ${ }^{72}$

The Scottish Parliament's Equalities and Human Rights Committee began to gather evidence on reform of the ban on prisoner voting in Scotland soon after the transfer of competence. During its deliberations the Lidington Compromise came into effect, but even though the Committee acknowledged that this settled the immediate human rights breach, it nonetheless concluded that it "seems unlikely that taking such an approach would address the various issues raised in evidence on the need for a more liberal approach to prisoner voting in Scotland". ${ }^{73}$ It concluded that the Scottish Parliament should remove all restrictions on prisoners voting in local elections in Scotland and elections for the Scottish Parliament. ${ }^{74}$ Faced with the daunting prospect of meeting the super-majority requirement, the Scottish Government were, perhaps unsurprisingly, much more cautious than the Committee. It followed up on the Committee report and a public consultation with proposals to enfranchising all prisoners serving sentences of under twelve months, under the Scottish Elections (Franchise and Representation) Bill. Having taken this decision, it even introduced a measure to extend the franchise to cover a by-election in Shetland ahead of debate on the Bill, in order to fulfil its human rights obligations. ${ }^{75}$

In a Scottish prison population of roughly 8000 , roughly 1500 remand, awaitingsentence and day release prisoners were already able to vote at the point at which this reform was proposed. The proposal thus had the potential to increase the number of enfranchised prisoners to around 2500 on any given election day. The section of the prison population impacted by the reform is therefore, in effect, the churn of short-term prisoners. The proposal, however, was being made alongside the Scottish Government's efforts to reduce the use of

\footnotetext{
${ }^{71}$ Donnelly v Edinburgh Electoral Registration Officer, 1964 SLT (Sh Ct) 80.

${ }^{72}$ For recognition of voting by prisoners in Scotland between 1949 and 1969 in the legislative debate over reform of the franchise, see B Kidd MSP, Scottish Parliament Official Report, 28 November 2019, col 67 and M Russell MSP, Scottish Parliament Official Report, 20 February 2020, col 93.

${ }^{73}$ Equalities and Human Rights Committee, Prisoner Voting in Scotland (14 May 2018) SP Paper 315, para 142.

${ }^{74}$ Ibid, para 145.

75 The Representation of The People Act 1983 Remedial (Scotland) Order 2019 (SSI 2019/261), passed under Convention Rights (Compliance) (Scotland) Act 2001, s 12.
} 
short-term prison sentences within Scotland's criminal justice system. ${ }^{76}$ As this policy shift takes effect it will reduce the number of prisoners affected by the reforms to the disenfranchisement rules.

Unlike the administrative approach adopted by the UK Government, the Scottish Elections (Franchise and Representation) Bill provided an opportunity for the rules regarding prisoner disenfranchisement to be subject to a legislative debate. For all that the Scottish Government embraced a broad conception of the societal connection necessary between a person and the polity necessary to qualify for the vote in enfranchising foreign nationals resident in Scotland through this legislation, the Constitution Secretary, Mike Russell, was notably more reticent about the democratic justifications for enfranchising prisoners; "The bill will achieve two distinct, but equally important, objectives: it will guarantee ECHR compliance with regards to prisoner voting, which we must do, and include in our franchise all who make Scotland their home, which we should do". ${ }^{77}$

When Adam Tomkins questioned this presentation of the Bill on the basis that the UK Government had already concluded the Hirst litigation, Russell responded that "the smaller the step that is taken, the greater the likelihood of challenge - there is a relationship between the two". ${ }^{78}$ Much has been written about the efforts of courts across the UK to keep pace with, and resist outrunning, Strasbourg's interpretation of the ECHR in their own human rights jurisprudence. ${ }^{79}$ Richard Bellamy has highlighted how this approach creates "leeway" for law makers to choose to move beyond the baseline of rights protections set by the courts as they interpret the ECHR rights. ${ }^{80}$ These interactions, however, suggest that on an issue as politically controversial as prisoner voting, law makers will often be reluctant to move into the space supposedly being provided by the domestic courts. The imposition of a super majority requirement in the Scotland Act 2016 further operated to restrict the scope for legislative creativity. A double dose of deference ensued, with both the domestic courts and

\footnotetext{
${ }^{76}$ The Presumption Against Short Periods of Imprisonment (Scotland) Order 2019 extended the presumption operative under the Criminal Justice and Licensing (Scotland) Act 2010 from operating against sentence of up to 3 months to sentences of up to 12 months.

${ }^{77}$ M Russell MSP, Scottish Parliament Official Report, 28 November 2019, col 65.

${ }^{78}$ Ibid, col 65.

${ }^{79}$ See R Masterman, "Taking the Strasbourg Jurisprudence into Account: Developing a 'municipal law of human rights' under the Human Rights Act 1998" (2005) 54 International and Comparative Law Quarterly 907.

${ }^{80}$ R Bellamy, "Political Constitutionalism and the Human Rights Act" (2011) 9 International Journal of Constitutional Law 86, 97.
} 
Scottish Parliament becoming transfixed upon acting exactly as Strasbourg requires, limiting discussion of the wider democratic implications of prisoner disenfranchisement.

The Scottish Elections (Franchise and Representation) Bill's prisoner voting provisions were thus explicitly presented as ensuring the minimal sustainable compliance with the ECHR; the Scottish Government did not seek to justify it on democratic grounds. The impact of the super-majority requirement, in short, was to turn the debate into one about the necessity, for competence purposes, of meeting human rights obligations, rather than an active consideration of the interaction between democracy and penal policy. Scotland nonetheless broke new ground within the UK's constitutional order when the Scottish Parliament passed these proposals into law on 20 February 2020, with 92 votes in favour and 27 against. ${ }^{81}$ The Scottish Government had successfully achieved not simply majority support for the enfranchisement of some prisoners, but the necessary super majority.

(2) Wales

Devolved law making in Wales has sometimes been said to run in the shadow of Scotland, especially in the period before devolution was reshaped and new competences provided to the Welsh Parliament through the Wales Act 2017. On issues of controversy, this has meant that Wales' devolved institutions have been able to draw on the experience of Scotland's efforts to legislate on an issue, and not have to break new ground in departing from the law applicable in other parts of the UK. For Richard Rawlings, this is a function of Wales being a part of the UK which was "obviously less well-placed than others to make the political and constitutional weather". ${ }^{82}$ The new dispensation under the Wales Act 2017, however, could see Wales' institutions transcend this role.

When the issue of prisoner voting came to be considered by the Equality, Local Government and Communities Committee, it was able to draw upon some of the debate that had already taken place in Scotland. ${ }^{83}$ These beginnings of Wales' distinct engagement with prisoner voting could be typecast as more of the "free riding" that Rawlings diagnoses. ${ }^{84}$ The Committee, however, quickly found that the interaction between the prison system and

\footnotetext{
${ }^{81}$ Scottish Elections (Franchise and Representation) Act 2020, s. 5.

${ }^{82}$ R Rawlings, "Riders on the Storm: Wales, the Union, and Territorial Constitutional Crisis" (2015) 42 Journal of Law and Society 471, 474.

${ }^{83}$ Equality, Local Government and Communities Committee, Voting Rights for Prisoners (June 2019) para 19.

${ }^{84}$ Rawlings, n 82, 474.
} 
electoral law was much more complex than in Scotland. With Wales being part of the criminal justice system of England and Wales, over a third of the prisoners ordinarily resident at a home address in Wales prior to their incarceration find themselves in prisons in England (including all female prisoners). ${ }^{85}$ Moreover, although the Welsh Parliament has competence over the franchise for devolved and local government elections insofar as they affect prisoners with home addresses in Wales, it remains in large part subject to criminal justice measures determined at Westminster. Moves by the UK Government to increase prison sentences for a range of offences could therefore pose serious implications for Wales, which has a higher per capita incarceration rate than England. ${ }^{86}$ The Committee must therefore have been aware that any such changes at Westminster could reduce the impact of Welsh measures which enfranchised prisoners if they were based on the short-term 12-month sentence threshold introduced in Scotland. ${ }^{87}$

These practical implications of introducing prisoner voting in Wales thus played a larger part in the Committee's deliberations than they had done in Scotland. The Committee nonetheless grounded their report in an extensive discussion of democratic principles, with a majority of the Committee relying upon this discussion to steel themselves in the face of opinion polling against prisoner voting; "We know that extending the franchise to prisoners is not popular. ... But that does not mean that extending the franchise is not the right thing to do" ${ }^{88}$ Although the need to achieve ECHR compliance played a considerable part in the Committee's report, this grounding saw the majority guided by "letter and spirit" of the Hirst judgment, rather than an effort to divine what minimal compliance required. ${ }^{89}$ It arrived at a recommendation that prisoners with a home address in Wales prior to incarceration should be enfranchised for Welsh Parliament and local government elections and enabled to vote by post or proxy if they are serving sentences of up to 4-years imprisonment. ${ }^{90}$ It noted explicitly that this marked the threshold by which the prison system already identified a long-term sentence. ${ }^{91}$

\footnotetext{
${ }^{85}$ Voting Rights for Prisoners, n 83, para 129.

${ }^{86}$ Ibid, p 14.

${ }^{87}$ The UK Government have since announced a policy driven by stricter minimum sentences, particularly for certain groups of repeat offenders; R Buckland, A Smarter Approach to Sentencing (2020) CP 292, para 82.

${ }^{88}$ Ibid, para 52.

${ }^{89}$ Ibid, para 123.

${ }^{90}$ Ibid, para 122.

${ }^{91}$ Ibid, para 122.
} 
The Welsh Government promptly accepted these recommendations, agreeing "that a custodial sentence of four years is an appropriate threshold, which acknowledges the nature, gravity and circumstances of the offending". ${ }^{92}$ Having taken this leap in the summer of 2019, shortly after the Scottish Government published the Scottish Elections (Franchise and Representation) Bill, the Welsh Government began to prevaricate. It moved ahead with reducing the minimum voting age to 16 and enfranchising foreign nationals legally resident in Wales for both local government and Senedd elections under the Senedd and Elections (Wales) Act 2020 and Local Government and Elections (Wales) Act 2020. Almost unnoticed, this legislation provided that 16- to 17- year olds held in "secure accommodation" could register to vote in their home constituency. ${ }^{93}$ When it came to the voting rights of the adult prison population, however, it delayed any move with regard to Senedd elections until after the 2021 election and its plans with regard to local elections were shelved amid the priorities of the coronavirus response. ${ }^{94}$ Once again, the super majority requirements were having a telling effect upon these proposals; the Welsh Government was not confident it could meet the 40 votes that would be required to get these proposals passed, and was not willing to engage in a political battle over the issue of prisoner voting against the backdrop of its pandemic response.

For all that the interconnection of legislative competence and respect for human rights obligations played a central (if, as we have seen, circumscribed) place in debates before the Scottish Parliament, and also in the Equality, Local Government and Communities Committee report, the Welsh Government has instead advanced electoral reforms which neglected prisoner disenfranchisement. Despite the Welsh Government acknowledging a preferred outcome and the significance of the right to vote, the hurdle imposed by the supermajority and the complexity introduced by the intertwining of England and Wales' criminal justice system combined to discourage it from addressing the prison franchise. In legislating to reform the franchise without addressing the issue of the ongoing breach of prisoners' voting rights, moreover, the Welsh Government risks having its competence to enact these measures challenged on human rights grounds. ${ }^{95}$

\footnotetext{
${ }^{92}$ Welsh Government Response (2019) p 1. Available at: http://www.assembly.wales/laid\%20documents/gen-ld12690/gen-ld12690-e.pdf. ${ }^{93}$ Senedd and Elections (Wales) Act 2020, s 19.

94 See "Coronavirus: Prisoner votes in Welsh local elections plan shelved" BBC News (8 April 2020). Available at: https://www.bbc.co.uk/news/uk-wales-politics-52221041.

${ }^{95}$ See the above discussion of $\operatorname{In} \operatorname{Re} G, \mathrm{n} 34$.
} 


\section{E. "BALANCING" THE RIGHT TO VOTE AND PENAL POLICY CONSIDERATIONS}

The core basis of a democratic society remains the principle of one person, one vote, of equal worth. ${ }^{96}$ As employed by the Strasbourg Court in Hirst, these "general principles"97 do not allow for groups of individuals to be disenfranchised because they are unpopular and indeed presume against the disenfranchisement of adult citizens resident in the state. ${ }^{98}$ Indeed, given that representative democracy exists as a means to mitigate the transaction costs which would be associated with direct democracy, ${ }^{99}$ law makers, who derive the legitimacy of their position from the operation of this principle, should not lightly undertake to restrict it. Even if the Scottish and Welsh Governments have been convinced that democratic principles support extending the prison franchise, the super-majority requirement has obliged them to seek as broad a coalition of legislators as possible to back reform.

This has meant that debates over prisoner voting have been characterised by appeals to the need for baseline compliance with the ECHR, and reforms have been couched as balancing democratic concerns against necessary retributivism within the criminal justice system. In Wales, the majority on the Equality, Local Government and Communities Committee couched their recommendations explicitly in terms of a balance between voting rights and penal policy considerations:

[T]his is a compromise that will help with reintegration and the inclusion of prisoners as part of our wider society, ensure compliance with the ECtHR ruling, both by the letter and spirit of the decision, will not be unduly complex to administer and recognise public concern by not proposing every prisoner is entitled to vote. ${ }^{100}$

\footnotetext{
${ }^{96}$ Given the extent to which it is invoked but not realised, Sandford Levinson prefers to describe this formulation as a "mantra" in the context of the United States; S Levinson, "One Person, One Vote: A Mantra in Need of Meaning" (2002) 80 North Carolina Law Review 1269, 1269.

${ }^{97}$ Kiss v Hungary (2013) 56 EHRR 38, [36]. Hirst v United Kingdom, n 1, [57]-[62].

98 The obligation generated by Article 3, Protocol 1 ECHR has been interpreted as being confined to citizens of the country in question; $R$ (Barclay) $v$ Lord Chancellor [2009] UKSC 9; [2010] 1 AC 464, [87] (Lord Collins). The Strasbourg Court has also been unreceptive towards using Article 3, Protocol 1 ECHR as the basis of "an obligation to enable citizens living abroad to exercise the right to vote"; Sitaropoulos v Greece (2013) 56 EHRR 9, [75].

99 T Khaitan, "Political Parties in Constitutional Theory" (2020) 73 Current Legal Problems 89, 94.

${ }^{100}$ Ibid, para. 123.
} 
Likewise, once the Scottish Government rejected the Equalities and Human Rights Committee's recommendation that all prisoners be enfranchised, it found itself obliged to justify its proposals to enfranchise prisoners serving sentences of up to 12 months by comparison to the UK Government's approach and the proposals for Wales. The Constitution Secretary emphasised his efforts to "strike the correct balance for Scotland":

We have our own justice system, with different temporary-release rules, so we need to make our own assessment of what is needed for ECHR compliance, just as the Welsh Government - and every other member state of the Council of Europe - has done. ${ }^{101}$

If the rationale for removal of the vote from some prisoners, but not others, is to be the seriousness of societal harm that an individual has caused, then the threshold requires careful consideration and clear justification. Indeed, the Hirst judgment emphasised the importance of such deliberation to the Court's application of the margin of appreciation. ${ }^{102}$ These comments, however, are difficult to accommodate with the judgment's substantive focus on the arbitrary effects of "a general, automatic and indiscriminate restriction on a vitally important Convention right". ${ }^{103}$ Any measure of disenfranchisement based around a sentence-length threshold will produce such effects; some prisoners serving an 18 month sentence will be disenfranchised because an election date falls within the time period of their incarceration, while others will not. ${ }^{104}$ In Canada, a legislative solution to prisoner voting litigation which relied upon a sentence threshold became the subject of renewed litigation and was ultimately found to breach the right to vote under the Canadian Constitution. ${ }^{105}$ The higher the chosen threshold, the fewer the instances in which the timing of the incarceration relative to an electoral cycle will make a difference, but any reform provides for a marked improvement upon the present system, under which the additional penalty of

\footnotetext{
${ }^{101}$ M Russell MSP, Scottish Parliament Official Report, 20 February 2020, col 97.

${ }^{102}$ Hirst $v$ United Kingdom, n 1, [79].

103 ibid, [82]. See also Scoppola v Italy, n 12, [96], affirming the incompatibility of a measure which "affects a group of people generally, automatically and indiscriminately, based solely on the fact that they are serving a prison sentence".

${ }^{104}$ See Murray, n 46, 107.

105 Sauvé v Canada (Attorney General) [1993] 2 SCR 438 and Sauvé v Canada [2002] 3 SCR 519.
} 
disenfranchisement can apply unevenly between two prisoners serving very short sentences simply because of the date on which an election falls.

A further problem with these debates is that as soon as the justification for a chosen threshold was couched in terms of "what is needed for ECHR compliance", ${ }^{106}$ then the debate inevitably became less focused on the principles at issue and more about what would be required to access the margin of appreciation which Strasbourg had held out in Hirst and Scoppola. Arguments swirled back and forth about whether it was necessary to legislate at all, when the Hirst case had been declared closed on the basis of the administrative enfranchisement of day-release prisoners. ${ }^{107}$ As legislatures in different parts of the UK adopt different positions on these questions it becomes increasingly difficult to say that that there is a shared conception of democracy at work within the UK constitution. If the Law Commissions have long maintained that electoral law has become 'complex, voluminous and fragmented', this is not simply the product of election-specific choices but of divergent accounts of what it means to be a democracy. ${ }^{108}$ Or, perhaps, different accounts of what Strasbourg says it means to be a democracy. For it is also difficult to maintain that democratic principles, as opposed to concerns over what constitutes minimal compliance with Strasbourg's jurisprudence, are driving these reforms. Scotland might have conducted a legislative debate over the appropriateness of a measure of prisoner disenfranchisement, in contrast to the sidelining of the Westminster Parliament inherent in the Lidington Compromise but, contrary to the European Court's intentions, those moving the legislation (and the MSPs who participated in the debates) were more engaged with the requirements of the Court's jurisprudence than with the task of espousing underlying democratic principles.

\section{F. CASES YET TO COME}

The Strasbourg jurisprudence, as it has developed after Hirst and particularly since Scoppola, has emphasised the need for clear justification of measures which disenfranchise some prisoners in legislative debate ${ }^{109}$ and explicitly affirmed that it was appropriate for the legislature to take account of the "gravity of the offence committed" in setting thresholds. ${ }^{110}$

\footnotetext{
${ }^{106}$ M Russell MSP, Scottish Parliament Official Report, 20 February 2020, col 97.

${ }^{107}$ A Tomkins MSP, Scottish Parliament Official Report, 28 November 2019, col 64.

${ }^{108}$ Law Commission and Scottish Law Commission, n 54, para 2.11.

${ }^{109}$ Anchugov and Gladkov v Russia App 11157/04 and 15162/05 (4 July 2013), [102].

110 ibid, [100].
} 
It has also downplayed the significance of the arbitrary effects of disenfranchisement based upon sentence length, although maintaining that the threshold of any sentence of imprisonment is disproportionate. ${ }^{111}$ This reemphasis of the jurisprudence, for all that it does not repudiate Hirst, was transparently an effort to de-escalate the quarrel between the Court and several ECHR states, but particularly the UK and Russia, over the application of Article 3 of Protocol 1 to prisoners. The more the Court has sought to defuse the dispute, however, the more confusion has resulted in what reforms would suffice to achieve compliance with Article 3 of Protocol 1, and the more debate has shifted from the principles at issue to interpreting the Court's decisions. The Court might well have "consistently highlighted ... that the rights guaranteed under art. 3 of Protocol No. 1 to the Convention are crucial to establishing and maintaining the foundations of an effective and meaningful democracy governed by the rule of law", ${ }^{112}$ but the application of those rights has become opaque where prisoner disenfranchisement is at issue, in light of the "wide margin of appreciation in imposing conditions on the right to vote and to stand for election". ${ }^{113}$

The shifting emphasis of this jurisprudence, even if the Court had clarified its core requirements by the time of its decisions in Scoppola and Anchugov and Gladkov, means that any partial enfranchisement of prisoners will eventually attract further litigation to test its compatibility with Article 3 of Protocol 1, even if Strasbourg's denial of costs and damages to the successor litigation to Hirst did much to dampen the volume of such claims. For all that the Council of Ministers declared Hirst closed on the basis of the Lidington Compromise, this arrangement cannot be considered stable. Even against a backdrop of the Court reemphasising the breadth of the margin of appreciation in such cases, the enfranchisement of a scant few prisoners on day release by administrative changes within the prison system does not provide a justified basis for maintaining the general legislative bar under the Representation of the People Act 1983 and if anything increases the level of arbitrariness in the process as it now matters whether the date of a day release aligns with an election day. Even if the European Court is reluctant to be drawn into a further damaging dispute with the UK, domestic courts are unlikely to simply incant the broad margin of appreciation.

\footnotetext{
${ }^{111}$ In the context of restrictions imposed in Hungry on the voting rights of people diagnosed with mental illnesses, Strasbourg used Hirst as a basis for reiterating "that this margin of appreciation is wide, it is not all-embracing"; Kiss v Hungary, n 97, [42].

${ }^{112}$ Davydov v Russia (2018) 67 EHRR 25, [272].

113 ibid, [272].
} 
A 12-month sentence threshold, subject to extensive legislative debate in the Scottish Parliament, therefore provides for a more secure solution. The ECHR is nonetheless a living instrument and the European Court's jurisprudence on prisoner voting could always become more prescriptive in the future, as more legal systems enfranchise more prisoners (evidencing a shift in Europe-wide attitudes on this issue). Furthermore, with the Welsh Government proposing to enfranchise all prisoners serving sentences of less than four years, MSPs might come to question the rationale behind the more restrictive provisions being proposed for Scotland. The Scottish Elections (Franchise and Representation) Act, indeed, intends for the issue to be revisited, in providing for a review of the operation of the 12-month rule by May 2023. ${ }^{114}$ For now, however, its provisions suffice for compliance with the current state of human rights law, and in such a review the operation of a measure of prisoner enfranchisement provides the Scottish Government with a repost to suggestions that societal norms or the democratic process are undermined by these reforms.

\section{G. REFERENDUMS YET TO COME}

The changes to the nature of the franchise for local and devolved legislature elections in Scotland and Wales point towards the increasing attenuation of "shared" understandings of the nature of democracy across the UK. The institution of devolution in 1998 brought with it complex set of electoral systems unique to each model within the asymmetric arrangements for devolution. Onto this has now been bolted distinct rules over the franchise in Wales and Scotland. The UK Parliament's Constitution Committee has been particularly exercised by the implications of devolution of these aspects of the franchise:

There is an argument that fundamental changes to the franchise should result instead from a UK-wide debate about what the franchise should be, or a more principled delineation of which body or bodies should have the power to decide the franchise for different polls. ${ }^{115}$

The meaning of democracy diverges across the UK. The emergence of these multiple understandings of democracy is not a matter of "the centre cannot hold", as the centre was

\footnotetext{
${ }^{114}$ Scottish Elections (Franchise and Representation) Act 2020, s 6.

${ }^{115}$ Constitution Committee, Proposals for the Devolution of Further Powers to Scotland (2015) HL 145, para 86.
} 
not particularly interested in holding. The enfranchisement of 16- and 17-year olds to enable them to participate in the Scottish independence referendum in 2014 pointed to the Scottish National Party's commitment to an expansive account of the franchise which would define democracy in Scotland differently from the remainder of the UK. The extension of this commitment into the enfranchisement of 16- and 17-year olds, legally resident foreign nationals and some prisoners for Scottish Parliament elections and local elections is not simply a matter of the Scottish Parliament cocking a snook at Westminster. The creation of distinct franchises is a significant marker of how distinct the Governments of Scotland, and indeed Wales, see these polities as being from other parts of the UK, and in the case of Scotland these developments must be seen against the backdrop of a potential second independence referendum.

The Northern Ireland border poll of 1973 provides a precedent that the franchise for a referendum on the status of a constituent part of the UK should be based upon the franchise for that polity's devolved legislature. ${ }^{116}$ A "general practice" has since been identified that "UK-wide referendums use the UK parliamentary franchise, while Scottish and Welsh referendums use the franchise for the Scottish Parliament and the Senedd". ${ }^{117}$ With the Scottish Parliament having created a distinct franchise, unique to Scotland, the Scottish Government will undoubtedly seek to have it apply in future referendums on Scottish independence. This connection attracted surprisingly little debate in the Scottish Parliament, with only one Conservative MSP raising complaints about the potential application of the extended franchise in future referendums. ${ }^{118}$ The UK Government might have believed that the super-majority threshold for altering electoral arrangements within the Scotland Act 2016 would stymie attempts to create a divergent franchise, but in doing so it failed to reckon with the groundswell in favour of distinct arrangements within Scotland and the general support that measures like the lowering of the threshold voting age has enjoyed since the experience of the 2014 referendum. ${ }^{119}$

\footnotetext{
${ }^{116}$ Northern Ireland (Border Poll) Order 1973 (SI 97/1973), Reg 2(1). See C Murray and A O’Donoghue, "Life after Brexit: Operationalising the Belfast/Good Friday Agreement's Principle of Consent" (2019) 42 Dublin University Law Journal 147, 182-183.

${ }^{117}$ Working Group on Unification Referendums on the Island of Ireland, Interim Report (2020) p 179.

118 J Halcro Johnson MSP, Scottish Parliament Official Report, 28 November 2019, col 70.

119 J Eichhorn, "Votes at 16: New insights from Scotland on enfranchisement" (2018) 71

Parliamentary Affairs 365, 367.
} 


\section{H. CONCLUSION}

Carl Stychin notes how Dicey retains his grip over the teaching of constitutional principles in UK law schools. ${ }^{120}$ The principles he invoked to define the Victorian constitutional order; parliamentary sovereignty, the rule of law and the separation of powers, are all more likely to feature more prominently in legal accounts of the UK constitution than democracy. If it features at all, democracy tends to be invoked as a legitimating factor behind parliamentary sovereignty, which provides the means by which popular sovereignty is effectively "absorbed by and channelled through Parliament". ${ }^{121}$ Doing so, however, tacks democracy into Dicey's constitutional order, rather than embedding the concept as a principle in its own right. Even as the UK Supreme Court recognises principles beyond Dicey's triumvirate, such as its decisive employment of parliamentary accountability in Miller and Cherry, ${ }^{122}$ this jurisprudence tends to focus on the institutional aspects of democracy rather than its manifestation through the right of individuals to participate in free and fair elections. ${ }^{123}$ The idea of common law right to vote, after all, fell on unreceptive ground in Moohan.

The recent extensions to the prison franchise have yet to illustrate a deeper account of democracy's place in the UK's constitutional order. The UK Government's extension of voting rights to day release prisoners was a transparent effort to avoid any parliamentary debate on the issue, even if the chosen response can hardly be said to satisfy the criticisms of the regime in place under the Representation of the People Act 1983. In Scotland, the Government presented its new legislation as an effort towards minimum compliance with human rights obligations. It celebrated extensions of local government and Scottish Parliament votes to foreign nationals resident in Scotland as securing an inclusive account of democracy, but was much more reticent when it came to the democratic value of prisoner voting. Wales has the opportunity to move beyond begrudging narratives of minimum compliance. In moving more slowly than Scotland, the Welsh Government is opening up the possibility of renewed litigation around the 2021 Welsh Parliament elections. But it is also

${ }^{120}$ C Stychin, "Rethinking legal methods after Brexit" (2019) 53 The Law Teacher 212.

${ }^{121}$ J Murkens, "Democracy as the legitimating condition in the UK Constitution" (2018) 38 Legal Studies 42, 48. Parliamentary sovereignty, for Keith Ewing, remains "the most democratic of all constitutional principles"; K Ewing, "Just Words and Social Justice" (1999) 5 Review of Constitutional Studies 53, 55.

${ }^{122} R$ (Miller and Cherry) v Prime Minister [2019] UKSC 41; [2020] AC 373, [46]-[48] (Baroness Hale).

${ }^{123}$ Ibid, [55] (Baroness Hale). 
able to take advantage of a space in which the practice of prisoner voting has been put into operation in Scotland without any resultant collapse of societal respect for law and order. With the displacement of such arguments, there is an opportunity for a policy to develop which prioritises the principle of one person, one vote, of equal worth. There is even the possibility that the enactment of a more generous dispensation in Wales will reinvigorate debates in Scotland and at Westminster. 